\title{
Article \\ Psychological Determinants of Attitude to Surgery in Internal Carotid Artery Stenosis Patients
}

\author{
Michał-Goran Stanišić ${ }^{1, *}$,, Teresa Rzepa ${ }^{2}$ and Przemysław Kubaszewski ${ }^{2}$ \\ 1 Department of Vascular and Endovascular Surgery, Angiology and Phlebology, \\ Poznan University of Medical Sciences, 61-848 Poznań, Poland \\ 2 University of Social Sciences and Humanities, 61-719 Poznań, Poland; trz@data.pl (T.R.); \\ kubaszewski@gmail.com (P.K.) \\ * Correspondence: michal.stanisic@angiodiabetica.pl or goranm@gazeta.pl; Tel.: +48-61-8549141
}

Citation: Stanišić, M.-G.; Rzepa, T.; Kubaszewski, P. Psychological Determinants of Attitude to Surgery in Internal Carotid Artery Stenosis Patients. Healthcare 2021, 9, 775. https://doi.org/10.3390/ healthcare 9060775

Academic Editor: Raffaele Giordano

Received: 25 April 2021

Accepted: 15 June 2021

Published: 21 June 2021

Publisher's Note: MDPI stays neutral with regard to jurisdictional claims in published maps and institutional affiliations.

Copyright: (c) 2021 by the authors. Licensee MDPI, Basel, Switzerland. This article is an open access article distributed under the terms and conditions of the Creative Commons Attribution (CC BY) license (https:// creativecommons.org/licenses/by/ $4.0 /)$.

\begin{abstract}
The basic way to prevent cerebral stroke in symptomatic 70-99\% stenosis of internal carotid artery (ICA) is an open or endovascular surgical procedure. Psychological research done so far among ICA stenosis patients focused on cognitive functioning changes. The objective was to assess attitude to surgery in relation to self-efficacy, life quality perception, and health locus of control in ICA stenosis patients. Materials and Methods: The study involved 53 asymptomatic ICA stenosis patients, aged from 53 to 81. Four scales were applied: Generalized Self-Efficacy Scale (GSES); Satisfaction With Life Scale (SWLS); Multidimensional Health Locus of Control Scale (MHLC); and a simple scale to examine the attitude to surgery, where "-10" stands for the maximally negative attitude, " 0 " - neutral, and " +10 " - maximally positive. The obtained results were put to statistical analysis. Results: It was found that women and men assessed their attitude to the surgery as positive $(M=7.92 ; S D=3.094)$, though the men estimated it slightly higher $(M=8.03 ; S D=3.02)$ than the women $(M=7.67 ; S D=3.37)$. The mean value of self-efficacy was high $(M=32.53 ; S D=6.231)$, and slightly higher for the men $(M=32.79 ; S D=5.576)$ compared to the women $(M=31.87 ; S D=7.836)$. The patients generally tended to manifest the external personal health locus of control $(M=28.62$; $S D=3.17)$. The runner-up was internal health locus of control $(M=26.02 ; S D=3.775)$, and the next one-external impersonal aspect (chance/luck) $(\mathrm{M}=23.57$; $\mathrm{SD}=4.457)$. The mean assessment of the patients' own life quality proved to be above average $(M=23.60)$ but varied $(S D=5.95)$. The women perceived the quality of their lives as better $(M=24.33$; $S D=6.422)$ than the men $(M=23.32$; $S D=5.818$ ). Very strong positive correlations were found between self-efficacy and life quality assessment $(p<0.001)$ and between the internal and external personal aspects of health locus of control $(p<0.007)$ in the women, and positive correlations were found between the attitude to surgery and internal health locus of control $(p<0.021)$ in the men. Conclusions: When breaking the news of a need to have a surgical intervention due to ICA stenosis, the physician should strongly refer to the value of human life and health. The message should arise from external (in the case of women) or internal (in the case of men) motivation to undergo surgery, and enhance the patient's conviction that the disease should be considered a challenge which must be taken to reverse their unfavorable situation and improve life quality.
\end{abstract}

Keywords: personal resources; internal carotid artery stenosis; stroke; psychological determinants

\section{Background}

Internal carotid artery stenosis (ICAS) is a recognized risk factor for cerebral stroke. Apart from pharmacological treatment, the basic way to prevent cerebral stroke is an open or endovascular surgical procedure [1]. Although a standard procedure in symptomatic internal carotid artery stenosis is open endarterectomy, there are still pending discussions about whether interventions are advisable in asymptomatic internal carotid artery stenosis and what kind of intervention to choose [2]. In light of the current research results, a surgical 
intervention for asymptomatic ICAS is justified when the stenosis is 70-99\% [3,4]. Despite the documented beneficial effects of surgical treatment for the patients' population, the individual risk in elective surgery is still high and, according to different sources of data, the cumulative risk of cerebral stroke, cardiac infarction and death may reach $1.5-6 \%$ regardless of the method applied: endarterectomy (CEA) or stenting (CAS) $[5,6]$. Qualifying an ICAS patient for surgical treatment requires the physician not only to understand the nature of the condition and the surgical treatment benefits for the patient, but also to know how the patient may react to the news of the need for surgery in the case of an asymptomatic condition.

Psychological research done so far among ICA stenosis patients focused on cognitive functioning changes, measured mainly after the surgery [7-11]. However, there are few studies on the requirements for a risky decision to be taken by patients who find themselves in a difficult situation in life $[12,13]$. Taking a decision to undergo surgery and developing a positive attitude to it requires activation of personal resources that allow the patient to cope with the sudden news of a fatal disease $[14,15]$. The resources include self-efficacy and health locus of control, as they ease the patients to manage the stressful situation related to the disease. The adaptation may be reinforced by a positive perception of patients' life quality. Previous research in the field of cardiovascular surgery shows fluctuations in health locus of control in peri-operative phases, requiring additional studies on specific disorders [16].

Self-efficacy is defined as a presumption that one is able to meet one's objectives, i.e., to make good decisions and cope with one's tasks even in unexpected and stressful situations $[17,18]$. Health locus of control is defined as an expectation that the present state is a result of external factors or one's own activities and exerting personal control [19]. Therefore, internal health locus of control is related to personal responsibility for a patient's health. Health locus of control may also be external: a subject may have the feeling of dependency on other people (e.g., health care providers) or on fate or chance [20,21]. Life quality assessment, in turn, is subject to dynamic changes and is based on the aggregated evaluation of physical health, general mental condition, status of relations with surrounding people, and fulfillment in their social and occupational roles [22,23].

The described constituents of personal resources underlie the mechanisms of coping with life challenges, which in the case of ICAS patients means unexpected initial news of a potentially serious disease and the need to undergo an invasive procedure.

The aim of the study was to assess attitude to surgery in relation to self-efficacy, life quality perception, health locus of control, and correlations between age, gender and attitude to surgery, and the above-mentioned constituents of personal resources in ICAS patients.

\section{Methods}

Consent was granted by the Research Ethics Committee; 53 asymptomatic ICA stenosis patients were recruited in a period of 6 months. The conditions of eligibility for the study were: asymptomatic disease for at least one year, elective admission, and the patient's consent to participate in the study in the pre-operative period. The examination involved persons admitted to a hospital and meeting the aforementioned criteria during psychologist visits held twice a month. During the visit, the psychologist was able to assess from 2 to 6 patients scheduled for carotid intervention for the next day or the day after. Such a system allowed for examination of about $50 \%$ of the weekly load of asymptomatic carotid patients treated in the department. Within the study period, two patients refused to take part in the assessment and were not included in the study population. Asymptomatic patients were chosen to eliminate the bias of emergency pressure from health care professionals in the case of symptomatic carotid disease. Before admission, patients had at least two scheduled consultations with a vascular surgeon and were subjected to two independent duplex scans of carotid arteries or one duplex assessment followed by angio-MRI or CT. 
The patients were not differentiated in terms of the kind of planned surgery (CAS/CEA) due to the comparable cumulative risk for both procedures [5].

The researching psychologist applied 4 scales, which were completed-with the help of the researcher-by the patients awaiting elective interventions in the university vascular surgery department. The tests, completed in the afternoon after regular medical assessment, were:

1. Generalized Self-Efficacy Scale (GSES, by R. Schwarzer and M. Jerusalem; adapted by Z. Juczyński), composed of 10 statements and measuring the level of general personal conviction regarding the individual's efficacy in handling tough situations [24];

2. Satisfaction With Life Scale (SWLS, by E. Diener, R.A. Emmons, R.J. Larson, and S. Griffin; adapted by Z. Juczyński), composed of 5 statements and measuring the generalized feeling of satisfaction with life so far [24];

3. Multidimensional Health Locus of Control Scale (MHLC, by K.A. Wallston, B.S. Wallston, and R. De Vellis; adapted by Z. Juczyński), composed of 18 statements and aimed at specifying their expectations in three aspects of health locus of control [24]. Thus, the study participant indicates whether their own health is controlled: (1) by them (internal aspect); (2) by other individuals, especially health professionals (external personal aspect); and (3) by fate/chance (external impersonal aspect);

4. A simple scale was applied to find the attitude to surgery, where " -10 " stands for the maximally negative attitude, " 0 " -neutral, and " +10 " - maximally positive.

Tests 1, 2, and 3 assessed mental dispositions of personal resources (self-efficacy, health locus of control, and life quality assessment), and test 4 assessed the type and intensity of patients' attitude to surgery.

The statistical analysis of the results was done by means of IBM SPSS Statistics 22 software (IBM, Armonk, NY, USA). To assess the normality of distribution of the analyzed variables, the Shapiro-Wilk test was applied. In order to specify the strength of correlation between the variables, Pearson correlation coefficient (r) was applied. The level of the anticipated impact of variables was verified by means of regression analysis in the singleand multivariable model.

\section{Results}

The study population consisted of 53 patients aged from 53 to $81(M=66.94 ; S D=8.05)$ who were recruited to the study and examined. The studied group included 15 women aged from 59 to $81(M=69.2 ; S D=6.75)$ and 38 men aged from 53 to $81(M=66.05$; $S D=8.42$ ).

It was found that the women and the men assessed their attitude to the surgery as positive $(M=7.92 ; S D=3.094)$, though the men estimated it slightly higher $(M=8.03$; $S D=3.02)$ than the women $(M=7.67 ; S D=3.37)$. The mean value of self-efficacy was high $(M=32.53 ; S D=6.231)$, and slightly higher for the men $(M=32.79 ; S D=5.576)$ compared to the women $(M=31.87 ; S D=7.836)$. The patients generally tended to manifest the external personal health locus of control $(M=28.62 ; S D=3.17)$. The runner-up was internal health locus of control $(M=26.02 ; S D=3.775)$, and the next one-external impersonal aspect (chance/luck) $(M=23.57 ; S D=4.457)$.

The mean assessment of life quality proved to be above average $(M=23.60)$, but varied $(S D=5.95)$. The women perceived the quality of their lives better $(M=24.33 ; S D=6.422)$ than the men $(M=23.32 ; S D=5.818)$.

The correlations between attitude to surgery, age, and gender proved to be statistically insignificant in relation to the totality of the patients. There were positive correlations between attitude to surgery and internal health locus of control $(p<0.004)$ and their own life quality assessment $(p<0.022)$. It was found that the variability of the internal health locus of control factor explained $13.4 \%$ of the patients' attitude to surgery variability $(F(1.51)=9.08 ; p<0.004)$.

Positive, statistically significant correlations were found between internal and external personal health locus of control $(p<0.002)$, between self-efficacy and life quality assessment 
$(p<0.000)$, between life quality assessment and external personal health locus of control $(p<0.037)$, and also between external personal and impersonal health locus of control $(p<0.028)$ (Table 1).

Table 1. Correlations between attitude to surgery, age, gender, and the selected constituents of personal resources in ICAS patients.

\begin{tabular}{|c|c|c|c|c|c|c|c|}
\hline Variables & Age & Gender & $\begin{array}{c}\text { Internal } \\
\text { Health Locus } \\
\text { of Control }\end{array}$ & $\begin{array}{c}\text { External } \\
\text { Personal } \\
\text { Health Locus } \\
\text { of Control }\end{array}$ & $\begin{array}{c}\text { External } \\
\text { Impersonal } \\
\text { Health Locus } \\
\text { of Control }\end{array}$ & Self-Efficacy & $\begin{array}{l}\text { Life Quality } \\
\text { Assessment }\end{array}$ \\
\hline Gender & $\begin{array}{l}-0.178 \\
0.203\end{array}$ & & & & & & \\
\hline $\begin{array}{l}\text { Internal health locus } \\
\text { of control }\end{array}$ & $\begin{array}{c}-0.041 \\
0.770\end{array}$ & $\begin{array}{l}-0.154 \\
0.272\end{array}$ & & & & & \\
\hline $\begin{array}{c}\text { External personal } \\
\text { health locus of control }\end{array}$ & $\begin{array}{l}0.008 \\
0.954\end{array}$ & $\begin{array}{l}0.031 \\
0.824\end{array}$ & $\begin{array}{c}0.415 ; p<0.01 \\
0.002\end{array}$ & & & & \\
\hline $\begin{array}{l}\text { External impersonal } \\
\text { health locus of control }\end{array}$ & $\begin{array}{l}0.123 \\
0.380\end{array}$ & $\begin{array}{l}0.052 \\
0.711\end{array}$ & $\begin{array}{l}0.235 \\
0.091\end{array}$ & $\begin{array}{c}0.301 ; p<0.05 \\
0.028\end{array}$ & & & \\
\hline Self-efficacy & $\begin{array}{l}0.003 \\
0.986\end{array}$ & $\begin{array}{l}0.067 \\
0.632\end{array}$ & $\begin{array}{c}-0.085 \\
0.543\end{array}$ & $\begin{array}{l}0.086 \\
0.539\end{array}$ & $\begin{array}{l}0.034 \\
0.809\end{array}$ & & \\
\hline Life quality assessment & $\begin{array}{l}0.116 \\
0.410\end{array}$ & $\begin{array}{c}-0.078 \\
0.580\end{array}$ & $\begin{array}{l}0.267 \\
0.053\end{array}$ & $\begin{array}{c}0.288 ; p<0.05 \\
0.037\end{array}$ & $\begin{array}{l}0.107 \\
0.448\end{array}$ & $\begin{array}{c}0.471 ; p<0.01 \\
0.000\end{array}$ & \\
\hline Attitude to surgery & $\begin{array}{l}0.153 \\
0.275\end{array}$ & $\begin{array}{l}0.053 \\
0.707\end{array}$ & $\begin{array}{c}0.389 ; p<0.01 \\
0.004\end{array}$ & $\begin{array}{l}0.262 \\
0.058\end{array}$ & $\begin{array}{l}0.074 \\
0.597\end{array}$ & $\begin{array}{l}0.202 \\
0.148\end{array}$ & $\begin{array}{c}0.314 ; p<0.05 \\
0.022\end{array}$ \\
\hline
\end{tabular}

The attitude to surgery taken by the female patients did not depend on their age, but it showed a strong positive correlation with external personal health locus of control $(p<0.043)$. Besides, it was found that the variability of this factor (external personal health locus of control) explained $22.5 \%$ of the variability in female patients' attitude to surgery $(F(1.13)=5.06 ; p<0.043)$

Moreover, very strong positive correlations were found between self-efficacy and life quality assessment $(p<0.001)$ and between internal and external personal health locus of control $(p<0.007)$ (Table 2).

Table 2. Correlations between attitude to surgery, age, and the selected constituents of personal resources in ICAS female patients.

\begin{tabular}{|c|c|c|c|c|c|c|}
\hline Variables & Age & $\begin{array}{l}\text { Internal Health } \\
\text { Locus of Control }\end{array}$ & $\begin{array}{c}\text { External } \\
\text { Personal Health } \\
\text { Locus of Control }\end{array}$ & $\begin{array}{l}\text { External Impersonal } \\
\text { Health Locus of } \\
\text { Control }\end{array}$ & Self-Efficacy & $\begin{array}{l}\text { Life Quality } \\
\text { Assessment }\end{array}$ \\
\hline $\begin{array}{l}\text { Internal health locus } \\
\text { of control }\end{array}$ & $\begin{array}{c}-0.229 \\
0.411\end{array}$ & & & & & \\
\hline $\begin{array}{l}\text { External personal health } \\
\text { locus of control }\end{array}$ & $\begin{array}{l}0.079 \\
0.781\end{array}$ & $\begin{array}{c}0.666 ; p<0.01 \\
0.007\end{array}$ & & & & \\
\hline $\begin{array}{c}\text { External impersonal } \\
\text { health locus of control }\end{array}$ & $\begin{array}{c}-0.478 \\
0.071\end{array}$ & $\begin{array}{l}0.414 \\
0.125\end{array}$ & $\begin{array}{l}0.107 \\
0.704\end{array}$ & & & \\
\hline Self-efficacy & $\begin{array}{l}-0.157 \\
0.575\end{array}$ & $\begin{array}{c}-0.110 \\
0.696 \\
\end{array}$ & $\begin{array}{l}0.010 \\
0.973\end{array}$ & $\begin{array}{c}-0.033 \\
0.908\end{array}$ & & \\
\hline Life quality assessment & $\begin{array}{l}-0.091 \\
0.748\end{array}$ & $\begin{array}{l}0.319 \\
0.247\end{array}$ & $\begin{array}{l}0.380 \\
0.163\end{array}$ & $\begin{array}{l}-0.120 \\
0.669\end{array}$ & $\begin{array}{c}0.756 ; p<0.01 \\
0.001\end{array}$ & \\
\hline Attitude to surgery & $\begin{array}{l}0.129 \\
0.648\end{array}$ & $\begin{array}{l}0.458 \\
0.086\end{array}$ & $\begin{array}{c}0.529 ; p<0.043 \\
0.043\end{array}$ & $\begin{array}{l}0.054 \\
0.848\end{array}$ & $\begin{array}{l}0.252 \\
0.365\end{array}$ & $\begin{array}{l}0.457 \\
0.087\end{array}$ \\
\hline
\end{tabular}

Among the male patients, no statistically significant correlations were found between age and attitude to surgery. However, there were positive correlations between attitude to surgery and internal health locus of control $(p<0.021)$. Besides, it was also found that the 
variability of this factor (internal health locus of control) explained $11.6 \%$ of the variability in male patients' attitude to surgery $(F(1.51)=5.86 ; p<0.021)$.

Positive correlations were also found between internal and external personal health locus of control $(p<0.035)$, between external personal and impersonal health locus of control $(p<0.034)$, and between self-efficacy and life quality assessment $(p<0.049)$ (Table 3$)$.

Table 3. Correlations between attitude to surgery, age, and the selected constituents of personal resources in ICAS male patients.

\begin{tabular}{|c|c|c|c|c|c|c|}
\hline Variables & Age & $\begin{array}{l}\text { Internal Health } \\
\text { Locus of Control }\end{array}$ & $\begin{array}{l}\text { External } \\
\text { Personal Health } \\
\text { Locus of Control }\end{array}$ & $\begin{array}{l}\text { External Impersonal } \\
\text { Health Locus of } \\
\text { Control }\end{array}$ & Self-Efficacy & $\begin{array}{l}\text { Life Quality } \\
\text { Assessment }\end{array}$ \\
\hline $\begin{array}{l}\text { Internal health locus } \\
\text { of control }\end{array}$ & $\begin{array}{l}-0.015 \\
0.930\end{array}$ & & & & & \\
\hline $\begin{array}{l}\text { External personal health } \\
\text { locus of control }\end{array}$ & $\begin{array}{l}-0.002 \\
0.989\end{array}$ & $\begin{array}{c}0.343 ; p<0.05 \\
0.035\end{array}$ & & & & \\
\hline $\begin{array}{l}\text { External impersonal } \\
\text { health locus of control }\end{array}$ & $\begin{array}{l}0.270 \\
0.101\end{array}$ & $\begin{array}{l}0.198 \\
0.233\end{array}$ & $\begin{array}{c}0.345 ; p<0.05 \\
0.034\end{array}$ & & & \\
\hline Self-efficacy & $\begin{array}{l}0.089 \\
0.596\end{array}$ & $\begin{array}{l}-0.055 \\
0.742 \\
\end{array}$ & $\begin{array}{l}0.121 \\
0.470\end{array}$ & $\begin{array}{l}0.057 \\
0.734\end{array}$ & & \\
\hline Life quality assessment & $\begin{array}{l}0.170 \\
0.307\end{array}$ & $\begin{array}{l}0.230 \\
0.164\end{array}$ & $\begin{array}{l}0.264 \\
0.110\end{array}$ & $\begin{array}{l}0.184 \\
0.269\end{array}$ & $\begin{array}{c}0.321 ; p<0.05 \\
0.049\end{array}$ & \\
\hline Attitude to surgery & $\begin{array}{l}0.180 \\
0.280\end{array}$ & $\begin{array}{c}0.374 ; p<0.05 \\
0.021\end{array}$ & $\begin{array}{l}0.169 \\
0.309\end{array}$ & $\begin{array}{l}0.079 \\
0.639\end{array}$ & $\begin{array}{l}0.169 \\
0.310\end{array}$ & $\begin{array}{l}0.255 \\
0.122\end{array}$ \\
\hline
\end{tabular}

Men gave higher notes $(M=8.03)$ than women $(M=7.67)$ not only to their attitude to surgery, but also to their self-efficacy (respectively: $M=32.79$ and $M=31.87$ ).

\section{Discussion}

The study results prove that in the case of internal carotid artery stenosis (ICAS) patients who suddenly, during out-patient consultation, face the news of the disease and are required to make a tough and risky decision on surgery, it is necessary to pay particular attention to their personal resources-particularly with regard to their mental dispositions showing a correlation with positive attitude to surgery, as an optimistic attitude has a positive influence on the treatment and recovery process [25-27], and in the case of this disease, on taking a decision to undergo surgery [28]. After all, not only asymptomatic ICAS patients, but even some physicians find it difficult to estimate the cerebral stroke risk for undergoing or not undergoing the surgical operation, due to ongoing discussion over asymptomatic carotid artery stenosis. Patients estimated the cerebral stroke risk following surgery to be even as much as $65 \%$ [12]. Other studies [13] showed that the higher the estimated risk was, the older the patients were, the more operations they had undergone in their adult years, the more often they did not have social support and the less trust they had in the medical staff (low results in the area of external personal health locus of control).

Based on the research study, we may assume that the more positive the attitude to surgery, the lower the level of the related, estimated risk. While risk estimation is a complicated task, depending on many factors, it is easier to influence the variables determining the attitude to surgery (in terms of its kind and intensity). Therefore, it was interesting to check what psychological resources were activated by the patients who formed and showed positive attitudes to surgery. It was established that-regardless of age and gender $[9,13]$ - patients were more positive the more they relied on personal control of their health and took responsibility for their health, and the more they valued their own life quality (Table 1). Besides, the variability of the major factor (internal health locus of control) explained $13.4 \%$ of the variability in attitude to surgery. This finding justifies formulating an important recommendation for physicians. Namely, they should talk to asymptomatic ICAS patients in such a way as to convince them of the possibility to take an independent and internally motivated decision on undergoing the surgery. Then, the news of the disease 
will be treated as a challenge that will activate the patient's personal resources and will induce the patient to take an effective decision [27-29]. A similar recommendation was formulated as a conclusion drawn from the comparative studies regarding internal carotid artery stenosis (ICAS) and abdominal aorta aneurysm (AAA) patients [29,30].

The correctness of the above-mentioned recommendation is confirmed by other findings, as it was found that the higher the level of internal health locus of control, the greater the trust in medical professionals (Table 1) [7] and the greater the faith in having good luck in the current life situation (Table 1). The correlation between these factors results in growing self-efficacy correlated with a higher assessment of life quality $(p<0.000)[13,28,29]$.

Although the above-described correlations and the recommendation addressed to physicians pertain to the totality of patients, they involve some gender-related subtleties. Namely, the observed correlations were mainly influenced by the results obtained from the ICAS male patients. Although the number of female patients involved in the study was small, it was found that their attitudes to surgery showed a strong positive correlation with external personal health locus of control (Table 2). This means that the women's attitudes are significantly dependent on information provided by and behavior of medical professionals [29]. Besides, it is worth noting that this finding confirms the common stereotype that women are more prone to suggestion. Since the variability of this factor explained as much as $22.5 \%$ of the variability of attitude to surgery, and since this significant result obtained by the female patients changed the overall sequence of aspects of health locus of control in favor of the external personal aspect, the recommendations for physicians communicating with ICAS female patients seem obvious. The more suggestive the communications used by physicians who-as it came out_constitute a strong external source of motivation for ICAS female patients, the bigger the chance to form positive attitudes to surgery $[12,13,28]$. The importance of this kind of motivation is proved by detailed statistical analyses showing that the greater the trust of ICAS female patients in medical professionals, the higher their self-efficacy in connection with a higher assessment of their own life quality (Table 2) and the greater the internal health locus of control (Table 2).

The above-mentioned gender differences were reflected in descriptive statistics, as it turned out that the men gave higher notes $(M=8.03)$ than the women $(M=7.67)$ not only to their attitude to surgery, but also to their self-efficacy (respectively: $M=32.79$ and $M=31.87$ ), even though the results were not reflected in assessment of their own life quality, which was more appreciated by the women (respectively: $M=23.32$ and $M=24.33$ ). These findings may also be explained by referring to the prevailing stereotypic perception of gender roles in the society. As men (according to the stereotype) "should be able to cope in each situation", self-efficacy seems to fit them more. Women, in turn (according to the stereotype) [31], because of playing socially desired functions, "should feel happy, as they are badly needed", and therefore should highly assess their own life quality.

Our study is limited to a specific disorder where the risk of ischemic stroke is the risk related to the disease and to the procedure. We assessed only asymptomatic patients and the researcher was present during the assessment creating a possible bias during specific test explanations.

\section{Conclusions}

Communicating the news of internal carotid artery stenosis, the physician should strongly refer to the value of human life and health, regardless of the gender and age of the patient.

The message should arouse external (in the case of women) or internal (in the case of men) motivation to undergo interventional treatment and reinforce the patient's conviction that the disease should be treated like a challenge, so as to change their unfavorable life situation and improve their life quality.

Author Contributions: Conceptualization, M.-G.S. and T.R. methodology, M.-G.S. and T.R.; software, P.K.; validation, all coauthors. formal analysis, all coauthors.; investigation, all co-authors.; resources, M.-G.S.; data curation, P.K., T.R.; writing-original draft preparation, M.-G.S., T.R.; writing-review 
and editing, M.-G.S. visualization, P.K.; supervision, M.-G.S. and T.R.; project administration, M.-G.S.; funding acquisition, M.-G.S. All authors have read and agreed to the published version of the manuscript.

Funding: This research received no external funding.

Institutional Review Board Statement: The study was conducted according to the guidelines of the Declaration of Helsinki, and approved by the Institutional Review Board (or Ethics Committee) of Poznan university of Medical Sciences (protocol code 51/14 and 16.01.2014).

Informed Consent Statement: Informed consent was obtained from all subjects involved in the study. Data Availability Statement: Original data sets are in disposition of co-authors of the manuscript.

Conflicts of Interest: The authors declare no conflict of interest.

\section{References}

1. Halliday, A.; Mansfield, A.; Marro, J.; Peto, C.; Peto, R.; Potter, J.; Thomas, D. MRC Asymptomatic Carotid Surgery Trial (ACST) Collaborative Group. Prevention of disabling and fatal strokes by successful carotid endarterectomy in patients without recent neurological symptoms: Randomised controlled trial. Lancet 2004, 363, 1491-1502.

2. Rudarakanchana, N.; Dialynas, M.; Halliday, A. Asymptomatic Carotid Surgery Trial-2 (ACST-2): Rationale for a randomised clinical trial comparing carotid endarterectomy with carotid artery stenting in patients with asymptomatic carotid artery stenosis. Eur. J. Vasc. Endovasc. Surg. 2009, 38, 239-242. [CrossRef]

3. Ferguson, G.G.; Eliasziw, M.; Barr, H.W.; Clagett, G.P.; Barnes, R.W.; Wallace, M.C.; Taylor, D.W.; Haynes, R.B.; Finan, J.W.; Hachinski, V.C.; et al. The North American Symptomatic Carotid Endarterectomy Trial: Surgical results in 1415 patients. Stroke 1999, 30, 1751-1758. [CrossRef] [PubMed]

4. Rothwell, P.M.; Gutnikov, S.A.; Warlow, C.P. European Carotid Surgery Trialist's Collaboration. Reanalysis of the final results of the European Carotid Surgery Trial. Stroke 2003, 34, 514-523. [CrossRef]

5. Mantese, V.A.; Timaran, C.H.; Chiu, D.; Begg, R.J.; Brott, T.G. CREST Investigators. The Carotid Revascularization Endarterectomy versus Stenting Trial (CREST): Stenting versus carotidendarterectomy for carotid disease. Stroke 2010, 41, S31-S34. [CrossRef] [PubMed]

6. International Carotid Stenting Study Investigators; Ederle, J.; Dobson, J.; Featherstone, R.L.; Bonati, L.; Van Der Worp, H.B.; De Borst, G.J.; Halloul, Z.; Gaines, P.; Dorman, P.J.; et al. Carotid artery stenting compared with endarterectomy in patients with symptomatic carotid stenosis (International Carotid Stenting Study): An interim analysis of a randomised controlled trial. Lancet 2010, 375, 985-997. [CrossRef]

7. Bakker, F.C.; Klijn, C.J.M.; Jennekens-Schinkel, A.; Kappelle, L.J. Cognitive disorders in patients with occlusive disease of the carotid artery: A systematic review of the literature. J. Neurol. 2000, 247, 669-676. [CrossRef]

8. Johnston, S.C.; O’Meara, E.S.; Manolio, T.A.; Lefkowitz, D.; O’Leary, D.H.; Goldstein, S.; Carlson, M.C.; Fried, L.P.; Longstreth, W.T., Jr. Cognitive impairment and decline are associated with carotid artery disease in patients without clinically evident cerebrovascular disease. Ann. Intern. Med. 2004, 140, 237-247. [CrossRef]

9. Voshaar, R.C.O.; Purandare, N.; Hardicre, J.; McCollum, C.; Burns, A. Asymptomatic spontaneous cerebral emboli and cognitive decline in a cohort of older people: A prospective study. Int. J. Geriatr. Psychiatry 2007, 22, 794-800. [CrossRef]

10. Witt, K.; Börsch, K.; Daniels, C.; Walluscheck, K.; Alfke, K.; Jansen, O.; Deuschl, G.; Stingele, R. Neuropsychological consequences of endarterectomy and endovascular angioplasty with stent placement for treatment of symptomatic carotid stenosis: A prospective randomised study. J. Neurol. 2007, 254, 1524-1532. [CrossRef]

11. Sztriha, L.; Nemeth, D.; Sefcsik, T.; Vecsei, L. Carotid stenosis and the cognitive function. J. Neurol. Sci. 2009, 283, 36-40. [CrossRef]

12. Lloyd, A.; Hayes, P.; Bell, P.R.; Naylor, A.R. The role of risk and benefit perception in informed consent for surgery. Med. Decis. Mak. 2001, 21, 141-149. [CrossRef]

13. Bosworth, H.B.; Stechuchak, K.M.; Grambow, S.C.; Oddone, E.Z. Patient risk perceptions for carotid endarterectomy: Which patients are strongly averse to surgery? J. Vasc. Surg. 2004, 40, 86-91. [CrossRef]

14. Baum, S.K.; Stewart, R.B., Jr. Sources of meaning trough the life-span. Psychol. Rep. 1990, 67, 3-14. [CrossRef]

15. Antonovsky, A. The sense of coherence as a determinant of health. In Behavioral Health; Matarazzo, J.D., Miller, N.E., Eds.; John Wiley: New York, NY, USA, 1984; pp. 114-129.

16. Rideout, A.; Tolmie, E.; Lindsay, G. Health locus of control in patients undergoing coronary artery surgery-changes and associated outcomes: A seven-year cohort study. Eur. J. Cardiovasc. Nurs. 2017, 16, 46-56. [CrossRef]

17. Bandura, A. Social Learning Theory; Prentice Hall Inc.: New York, NY, USA, 1977.

18. Bandura, A. Self-efficacy mechanism in human agency. Am. Psychol. 1982, 37, 122-147. [CrossRef]

19. Rotter, J.B. Generalized expectancies for internal versus external control of reinforcement. Psychol. Monogr. Gen. Appl. 1966, 80, 1-28. [CrossRef]

20. Wallston, K.A.; Wallston, B.S. Who is responsible for your health? The construct of health locus of control. In Social Psychology of Health and Illness; Sanders, G.S., Suls, J., Eds.; Erlbaum: Hillsdale, NJ, USA, 1982; pp. 65-95. 
21. Wallston, K.A.; Stein, M.J.; Smith, C.A. Form C of the MHLC Scales: A condition-specific measure of locus of control. J. Pers. Assess. 1994, 63, 534-553. [CrossRef]

22. Peterman, A.H.; Cella, D. Quality of life. In Encyclopedia of Psychology; Kazdin, A.E., Ed.; Oxford University Press-American Psychological Association: Oxford, UK, 2000; Volume 6, pp. 401-495.

23. Pavot, W.; Diener, E. The Satisfaction with Life Scale and the emerging construct of life satisfaction. J. Posit. Psychol. 2008, 3 , 137-152. [CrossRef]

24. Juczyński, Z. Narzędzia Pomiaru w Promocji i Psychologii Zdrowia [Measurement Tools in Health Promotion and Health Psychology]; Pracownia Testów Psychologicznych Polskiego Towarzystwa Psychologicznego [Psychological Test Lab of the Polish Psychological Association]: Warsaw, Poland, 2001.

25. Zotti, A.M.; Balestroni, G.; Cerutti, P.; Ferrario, S.R.; Angelino, E.; Miglioretti, M. Application of the General Perseived Self-Efficacy Scale in cardiovascular rehabilitation. Monaldi Arch. Chest Dis. 2007, 68, 178-183. [PubMed]

26. Biopsychosocial Aspects of Health and Disease; Janowski, K.; Steuden, S. (Eds.) CPPP Scientific Press: Lublin, Poland, 2009.

27. Szramka-Pawlak, B.; Dańczak-Pazdrowska, A.; Rzepa, T.; Szewczyk, A.; Sadowska-Przytocka, A.; Żaba, R. Quality of life and optimism in patients with morphea. Appl. Res. Qual. Life 2014, 9, 863-870. [CrossRef]

28. Stanisić, M.; Rzepa, T. Attitude to one's illness vs. Attitude to a surgical operation, displayed by patients diagnosed with asymptomatic abdominal aortic aneurysm and asymptomatic internal carotid artery stenosis. Int. Angiol. 2012, 31, 376-385.

29. Kościelak, R. Poczucie Umiejscowienia Kontroli i Przekonania o Własnej Skuteczności w Zdrowiu i Chorobie [Health Locus of Control and Conviction of Self-Efficacy in Health and Sickness]; IMPULS: Kraków, Poland, 2010; pp. 39-40.

30. Rzepa, T.; Stanisić, M.-G. Reasons underlying the consent to endovascular treatment, displayed by patients diagnosed with asymptomatic internal carotid artery stenosis. Med. Sci. Monit. 2014, 20, 1503-1509. [CrossRef] [PubMed]

31. Puddifoot, K. Stereotyping Patients. J. Soc. Philos. 2019, 50, 69-90. [CrossRef] [PubMed] 